\title{
Ideological Adaptation? The Survival Instinct of Threatened Legislators
}

\author{
Thad Kousser University of California, San Diego \\ Jeffrey B. Lewis University of California, Los Angeles \\ Seth E. Masket University of Denver
}

\begin{abstract}
Do legislators remain at one point on the ideological spectrum for their entire careers, or do they update their ideological positions in response to the demands of constituents? Although theories of the electoral connection predict that legislators should adapt to voter demands, most empirical studies instead show that they maintain consistent positions in the face of changing political conditions. This article takes advantage of the natural experiment provided by California's 2003 recall election - held at the midpoint of the state's legislative session— to investigate the impact of a strong electoral signal that is isolated from other political changes. We show that after the results of the recall signaled a surge in support for the Republican Party, Democratic legislators, particularly those in the most competitive districts, moderated their voting behavior in an apparent case of ideological adaptation.
\end{abstract}

\begin{abstract}
"[M]embers of Congress die in their ideological boots. That is, based upon the roll call voting record, once elected to Congress, members adopt an ideological position and maintain that position throughout their careers."
\end{abstract}

$$
\text { —Keith Poole (1998, p. 3) }
$$

A

central tenet of American legislative scholarship over the last 30 years holds that legislators are predominately, if not single-mindedly, motivated by electoral incentives. This notion is echoed by the popular media, which often characterize legislators as pandering or lacking political courage. Yet there is little empirical evidence that legislators actually adjust their voting behavior in response to partisan and ideological shifts in the electorate. Poole's (1998) frequently cited conclusion that members of Congress maintain consistent ideological positions through their often long tenures is consistent with a large number of studies which find that members generally do not adapt their ideological positions in response to changes in their electoral environments. Whether the change in electoral condition is the result of redistricting (Poole 1998; Poole and Romer 1993), a switch in office (Grofman, Griffin, and Berry 1995), or the removal of the electoral constraint through the decision to retire (Lott 1987; Lott and Bronars 1993; Van Beek 1991), studies generally reveal little subsequent shift in roll-call voting behavior. ${ }^{1}$

While it could be that legislators are not as electorally motivated as is commonly thought, there is reason to believe that the research designs used to probe for shifts in legislative voting behavior often lack sufficient power to detect change. In many cases, an electoral shock large enough to induce a member to change her voting behavior is accompanied by a host of other changes to the legislative environment, including shifts in chamber membership, committee rosters, partisan control of the legislature, and the

\footnotetext{
${ }^{1}$ These findings of ideological stability are buttressed by Levitt's (1996) research, which shows that senators rely overwhelmingly on their (fixed) ideologies, rather than changing constituent preferences or party pressures, when casting votes. Yet several other studies have called these findings of ideological fixity into question. Hibbing (1986) discovers that U.S. representatives alter their roll-call voting behavior when they plan to run for a Senate seat. Crook and Hibbing (1985) show that the congressional reforms of the 1970s caused committee chairs to raise their party support scores. Figlio (1995), Tien (2001), and Snyder and Ting (2003) have found evidence of legislative "shirking" in the final terms of retiring legislators. Jenkins (2000) and Wright and Schaffner (2002) found that roll-call voting loses its ideological consistency in "partyless" legislatures, and Grossback, Peterson, and Stimson (2005) show that legislators react to mandates indicated by vote shifts in their districts.
}

The Journal of Politics, Vol. 69, No. 3, August 2007, pp. 828-843 
chamber's policy agenda. Indeed, such a shock could potentially bring about the legislator's own removal from office. It is thus difficult to isolate the effects of changes in the electoral environment on legislative voting behavior. A more favorable empirical situation is one in which members perceive a large shock to their beliefs about the political preferences of their voters, but that shock is isolated from other changes in the legislative environment. In such a natural experiment, the change in electoral conditions would not be brought about by members' individual decisions to retire or to run for other offices or by a political process such as redistricting in which members' electoral prospects are explicitly taken into account.

We argue that the 2003 California gubernatorial recall provides exactly this rare empirical opportunity to isolate the effect of changes in constituency preferences on legislative behavior. ${ }^{2}$ In what follows, we demonstrate that Democratic members of the California Assembly moderated their ideological positions following the 2003 recall of Democratic Governor Gray Davis. In that election, Davis was rebuked not only by a majority of the state's voters, but by a majority of voters in 18 of the 48 Assembly districts held by Democrats. We find that as these threatened members shifted toward the center of ideological spectrum, the new Republican Governor Arnold Schwarzenegger gained an average of one to two extra Democratic votes on contested roll calls during his first year in office.

By taking advantage of this natural experiment, we show that the electoral connection can indeed motivate legislators to adjust their behavior in response to a strong signal that their constituents have shifted. They do not maintain their well-worn ideological positions until the process of natural selection eliminates those who are not fit for the new political age. Instead, they evolve, adapting to their new environment in order to survive the next election. The Downsian forces that pull candidates toward the median voter in a district can exert their influence

${ }^{2}$ While the circumstances of California's recall and the characteristics of its candidates are certainly unique, the signal that it sentthat many voters shifted their support from one party to the other-is quite common in democratic politics. The resulting shifts in legislative positions that we find here should be evidence of a general phenomenon that could be further investigated in state politics by using the data sets on gubernatorial approval and legislative roll calls that have now been made available by researchers at the University of North Carolina and at Indiana University, respectively. These more general tests, though, would lack the unique feature of the recall that is most useful to our research design: the executive election was held independent of any legislative contests, allowing us to isolate the effects of its signal. more than once, with legislators repeatedly updating their positions to keep in line with their constituents. This finding fits with theoretical expectations about legislative behavior, but challenges much of the recent empirical literature.

\section{The California Recall as Natural Experiment}

When Governor Arnold Schwarzenegger called California lawmakers "girlie men" at a political rally in the summer of 2004, his Saturday Night Live-inspired put down was only one part of the message he attempted to send to his uncooperative state legislature. The mere presence of this international celebrity in a San Bernardino County mall was a reminder to legislators stalling his plans in Sacramento of how popular he was in their districts. It was also an attempt to hark back to the October, 2003 recall. During that election, voters in 18 of the 48 Assembly districts held by Democrats cast a majority of their ballots in favor of removing Democratic Gov. Gray Davis (as did voters in 28 of the 32 seats held by Republicans). The two Republican replacement candidates, Schwarzenegger and Tom McClintock, won a combined majority of the vote in 23 Democrat-held seats (California Secretary of the State 2003b). Gov. Schwarzenegger's jibe, delivered in one of these districts, sought to highlight the legislators' electoral vulnerability in order to force concessions during a policy standoff. This paper investigates how successful he was and in the process explores how this unique natural experiment sheds light on more general questions about the links between constituent preferences, elections, and legislative behavior.

America's second gubernatorial recall-North Dakota's voters recalled Governor Lynn Frazier in 1921 — came as a sudden and unexpected shock to California politicians. Since every California governor for decades has had recall petitions circulated against him, few observers took the matter seriously until the recall campaign received a massive infusion of cash from aspiring replacement candidate Darrell Issa in late April of 2003. Popular support for the recall did not reach $50 \%$ until July of 2003 , and polling as late as August showed the governorship likely to remain in Democratic hands (Kousser 2004, 309-12). It was not until shortly before the October 7 th election that the seismic shift in California politics became apparent.

Although the strong Republican swing in this election may have caused vulnerable Democrats to quake, the replacement of Gray Davis with Arnold 
Schwarzenegger left virtually all other aspects of the political environment unchanged. ${ }^{3}$ The state's large budget deficit and the unpopularity of Gray Davis remained constant over our period of study: Lawmakers were already borrowing billions to pass a budget in the summer of 2002, and Davis' approval ratings reached only $39 \%$ when he was reelected that November (Kousser 2004, 307). After Davis was recalled the next year, California's other seven statewide-elected officials all remained in office. The membership of both the Assembly and Senate remained constant. Committee rosters were unchanged, and both the year before and the year after the recall featured parallel progressions of bills through policy committees, fiscal committees, and the floor in each house. There were no scandals, major initiative battles, or other events to cloud the effect of the recall.

The message of the isolated electoral signal sent by 2003 recall was clear: voters had soured on California's Democratic leaders since November, 2002. Gray Davis, who had won a $47 \%$ to $42 \%$ victory in his reelection campaign less than a year before, was recalled by a $54 \%$ to $46 \%$ margin. The two leading Republicans in the replacement contest combined to capture $62.1 \%$ of the vote, with moderate Arnold Schwarzenegger winning $48.6 \%$ and conservative Tom McClintock taking 13.5\%. Lt. Governor Cruz Bustamante, a Democrat who had been reelected to that post with $49.4 \%$ of the vote in 2002 , drew a mere $31.5 \%$ in the race to replace Davis (California Secretary of the State 2002b, 2002c, 2002d, 2003b). Seventy-three percent of Californians at the time agreed with the statement that the state was "seriously off on the wrong track" (Los Angeles Times Poll 2003), and only 19\% approved of the job the Legislature was doing (DiCamillo and Field 2004, p. 5). Looking at these figures and the results of the recall, Democrats in the Legislature had reason to be worried.

The outcome of the recall election conveyed information about what each district's voters wanted and, in this sense, was a poll that was specific to each district and broadcast to everyone. The message could be understood in one of two largely observationally equivalent ways. In a simple spatial framework, the recall could reflect a rightward shift in the location

${ }^{3} \mathrm{~A}$ similarly sharp and severe break in legislative behavior came when Vermont Senator Jim Jeffords left the Republican Party and caucused with the Democrats in May, 2001 (Den Hartog and Monroe 2006). The distinction, of course, is that there was no electoral signal in the Jeffords case. The shock was a shift in party control of the Senate while constituent preferences remained constant; our natural experiment identifies a shift in constituent preferences while party control is unchanged. of the median voter away from the Democrats Davis and Bustamante and towards the Republican Schwarzenegger. Alternatively, the recall might reflect a shift in the electorate's assessment of legislative competence of the Democratic Party. That is, rather than a shift in position, the recall might have revealed a shift in the valence associated with each of the major parties (Groseclose 2001). Under the first interpretation, the cut point along a policy or ideological dimension that divides Democratic voters from Republican voters remained fixed and the voters shifted rightward. Under the second interpretation, the locations of the voters were unchanged, but the cut point dividing Democrat from Republican voters shifted leftward. In either case, the effect was the same: many moderate voters who had previously supported Democrats broke ranks in the recall. And, in either case, Democrats would have incentives to moderate their positions in order to win those moderate voters back and Republicans would have incentives to challenge Democrats in districts which had previously been considered safely Democratic. These incentives should be especially sharp in the districts where the partisan shift was strongest.

We expect those considering a run for Assembly, especially strong contenders with office-holding experience, to respond to the change the electoral landscape revealed by the recall. This follows from the logic outlined in Jacobson and Kernell's (1983) study of strategic entry by congressional candidates, and the evidence in favor of it shows that the recall results were taken seriously by California politicians. Our models, presented in the next section, predict whether each party nominated a candidate with prior elected office experience in the 2002 and 2004 primaries. We find significant shifts in candidate quality. In districts where the recall sent a strong message of Republican resurgence, the Republican primary was more likely to produce a nominee with prior elective experience while the Democrats were less likely to find a "high quality" candidate. We take these findings on entry as a sort of lemma needed to establish that Democrats moderated their roll-call voting records in response to a perceived change in electoral conditions. What this lemma shows is that office seekers acted as if electoral battleground had been redrawn by the recall, buttressing the notion that Democratic members of the legislature felt more vulnerable after the 2003 election.

If the recall marked a rightward shift in the electorate and an increased electoral vulnerability for Assembly Democrats, we expect that voting records of those Democrats would moderate. It is less clear how Republican members should respond to the shift in 
this electoral environment. On the one hand, one might expect that Republicans emboldened by the recall should shift rightward. On the other hand, Assembly Republicans might conclude from the recall that they have an opportunity to take majority control Assembly if they strike a more moderate chord. Because of these ambiguities, we focus our attention on the more clear-cut expectation that Assembly Democrats will shift rightward.

To test this prediction, we shift our focus from California's 80 Assembly districts to its capitol. After beginning with a friendly approach that included calling Sacramento's top legislative leader "a great human being" (Ainsworth 2004), Gov. Arnold Schwarzenegger responded to a budget stalemate with a campaign aimed at reminding an uncooperative Legislature about the lessons of his 2003 victory. He focused his attention on those legislators with the greatest incentives to respond to the recall's electoral message. In July, 2004, Schwarzenegger visited six competitive Assembly districts to convince the Democrats who held them to compromise on the budget or be "terminated" at the polls (Bluth 2004). In a Long Beach diner, he warned that "Judgment day is in November. I want the people to know that in November is the election. If they're not satisfied with the budget, then there will be a lot of new faces after the November election." Commenting on these trips, his communications direction mused, "We'll see how [legislators] respond after tasting steel for 72 hours" (Nicholas and Halper 2004). Finally, the governor attracted national attention at an Ontario mall by saying that the legislators opposed to his budget were "girlie men" (Ainsworth 2004).

Vulnerable Democrats did not quickly crumble on the budget. But our analysis shows that in the roll-call votes that they cast after the recall, Democrats in competitive seats moved much closer to the center than they were in the year leading up to the recall. Our parallel analyses of three previous sessions show that this is not the result of a natural election year effect. The political impact of this ideological shift can be seen in votes such as the repeal of a bill that would have granted driver's licenses to undocumented immigrants. ${ }^{4}$ The shift was statistically significant and sharpest for the most electorally vulnerable Democrats.

${ }^{4}$ In the most obvious shift in voting behavior brought by the recall, many Assembly members reversed their position on Senate Bill 60, which would have allowed the Department of Motor Vehicles to issue driver's licenses to California residents who did not have a

\section{The Recall and Strategic Candidate Entry Decisions}

Did the Republican surge made evident by the recall make legislative races more attractive to potential Republican office seekers in 2004 than they were in 2002? If so, we should observe a ceteris paribus increase in the chances that Republicans nominated experienced candidates for the Assembly, ${ }^{5}$ with the rise being especially large where Republican candidates performed particularly well in the recall's replacement race. Conversely, experienced Democrats should have been scared off by the lack of support for their party's standard bearers and run in lower numbers than expected. Because Assembly candidates for both parties' nominations had to declare their intention to run in 2004 by a November 10, 2003 deadline, the results of the October 7, 2003 recall election should have weighed heavily in their minds (California Secretary of the State 2004c).

Our models use the same sort of measure that is featured in Jacobson and Kernell's (1983) empirical tests of their theory of strategic candidate entry: Whether or not each party's nominee ${ }^{6}$ in an Assembly district had previously held elective office. Using biographical sources, ${ }^{7}$ we categorized each major party's

legal presence in the United States. This bill passed on the Assembly floor by a 44 to 31 vote, was signed by Davis on September 5, 2003, and became a lightning rod for criticism during the recall campaign. Governor Schwarzenegger made its repeal one of his first priorities, and the bill to repeal it, SBX3, passed by a 64-69 margin in the Assembly and was signed on December 2, 2003, before SB60 ever went into effect (Legislative Counsel 2005).

${ }^{5}$ In this section and in all of the empirical analyses presented here, we look exclusively at California's 80-member Assembly and not at its 40-member Senate. Because elections for the Senate's four-year terms are staggered, only 20 of its seats were contested in 2004. In these seats, nine incumbents were prevented from running for office because of term limits (California Journal and Statenet 2004). While the 11 incumbents eligible for reelection in 2004 should in theory respond to the signals of the recall in the same way that Assembly members did, there are simply not enough cases here to estimate models of their behavior and of the actions of their challengers.

${ }^{6}$ Because of the difficulty in finding comprehensive biographic information on those who ran in a primary but lost, our empirical analysis examines whether the eventual nominee was a quality candidate rather than whether the primary field contained any quality candidates. In the rare case that an experienced candidate lost the primary to an inexperienced one, our coding scheme would fail to count him or her.

${ }^{7}$ For 2004 nominees, our biographical information came from The California Targetbook, a district-by-district analysis prepared for the press and political consultants (Hoffenblum 2004). For each 2002 nominee, we compiled biographical information from the profiles posted at http://www.smartvoter.org and http:// 
nominee in 2002 and 2004. We coded as "high quality" those who currently or previously held public office in California, most frequently a school board, city council, or county supervisor seat, but in some cases a seat in the state legislature or in Congress. We coded nominees who had never held political office (including college students, businessmen, actor/activists, ${ }^{8}$ or mediator/sky divers) as "low quality." We created another category, "mid-quality," for those elected or appointed to a minor office (such as a local planning board, community college trustee board, or a port commission) or elected to a county party's central committee. Since we divide our measure into three categories of increasing quality, but are unwilling to assume that the jump from a "low quality" to a "midquality" candidate is as large as the next step up to a "high quality" nominee, we estimate ordered probit models in the analysis that follows.

Using one model for each party, we combine data on the 2002 and 2004 Assembly primaries to see whether the 2003 recall signal affected candidate quality, holding constant other relevant factors. These factors include a district's party registration, ${ }^{9}$ the presence of an incumbent, ${ }^{10}$ average household incomes, ${ }^{11}$

www.calvoter.org and from searches on http://www.google.com identifying nominees as Assembly candidates. Our lists of nominees came from California Secretary of the State (2002a, 2004a).

${ }^{8}$ The reader probably has not heard of Paul Morgan Fredrix, the Republican nominee for the Hollywood/Beverly Hills-based 42nd Assembly District in 2004, who is an actor, activist, and attorney. But the reader may have seen him play opposite Erik Estrada in the 1999 feature film, Anaconda 2: King Cobra.

${ }^{9}$ We measure a district's party registration by the Democratic share of major party registration at the last reporting deadline before each primary (California Secretary of the State 2002a, 2004a). This should be the principal signpost telling potential candidates whether or not they are in friendly political territory. In the Republican strongholds of Orange County, suburban San Diego, and in the state's sparsely populated north, favorable partisan composition should encourage higher quality Republican candidates to enter. The pattern should be reversed in strongly Democratic districts in Los Angeles and the San Francisco Bay Area.

${ }^{10}$ The presence of incumbents, who rarely lose in either primary or general elections in California, should discourage potential candidates of both parties from running. Our models also allow the intimidating power of incumbency to vary with the incumbent's voting behavior, measured by the first-dimension NOMINATE estimate of his or her ideal point in the first half of the legislative session. We interact the presence of an incumbent with this figure to see whether, controlling for a district's partisanship, challenger decisions are influenced by the positions of incumbents seeking reelection.

${ }^{11}$ We measure a district's average household income in thousands of dollars (California Statewide Database 2004) and hypothesize that richer districts may give local officeholders access to the resources to make a serious bid for the Assembly, encouraging them to run. and the district's racial and ethnic composition. ${ }^{12}$ Our data sources for these variables and their hypothesized effects are described in footnotes. But the key causal variables that we focus on in this section measure the strength of the signal sent by the October, 2003 recall results that 2004 might be a good year for Republicans.

To capture this signal, our models include a dichotomous variable indicating that an observation represents a race from the 2004 election (rather than from 2002) as well as an interaction between this year indicator and a measure of the magnitude of the Republican surge. Our gauge of the relative strength of the surge in each district is the difference between the share of the gubernatorial vote won by the two Republican candidates in the 2003 recall, Arnold Schwarzenegger and Tom McClintock, and the share won by the Republican nominee in 2002, Bill Simon (California Secretary of the State 2002c, 2003b). This surge averaged 18.6 percentage points statewide, but varies considerably across districts. The weakest surge, of 2.2 percentage points, came in San Francisco's strongly Democratic 13th Assembly District, where the recall itself was defeated by an $83 \%-17 \%$ margin. The strongest surge, 26.4 percentage points, came in the San Bernardino-based 62nd Assembly District, a Democratic-leaning part of Southern California's "Inland Empire" where Bill Simon had performed poorly in 2002 but where Schwarzenegger and McClintock together won a clear majority. This is just the sort of district in which the recall results may have motivated formerly pessimistic Republicans to reevaluate their chances and throw their hats into the ring.

Table 1 confirms our expectation that the signal of the recall was taken seriously enough that it altered the entry decisions of legislative candidates. It presents the results of our ordered probit models as first differences, showing how shifts in explanatory factors change the probability that a party in a typical district ${ }^{13}$ will nominate a high-quality candidate. (A table

\footnotetext{
${ }^{12}$ We record the percentages of each district's residents who are black, Latino, or Asian-Pacific Islander (California Statewide Database 2004) and expect that districts containing more members of each racial and ethnic group will be more attractive to Democratic candi-

dates and will be less likely to feature high-quality Republican contestants.

${ }^{13}$ This typical district has no incumbents and mean levels of Democratic registration $(62.3 \%)$, income $(\$ 63,995)$, Latino population (35.4\%), black population (7.5\%), and Asian-Pacific Islander population (12.5\%). The model predicted that Republicans in a district like this nominated a low-quality candidate with a probability of $46 \%$, a mid-quality candidate with a probability of $21 \%$, and a high-quality candidate with a probability of $33 \%$. For
} 
TABLE 1 Explaining the Quality Level of Major Party Nominees, 2002 and 2004

\begin{tabular}{|c|c|c|c|}
\hline When this variable & Shifts from ... to ... & $\begin{array}{l}\text { Change in the Probability } \\
\text { that Republican is a High } \\
\text { Quality Candidate (upper } \\
\text { and lower bounds) }\end{array}$ & $\begin{array}{l}\text { Change in the Probability } \\
\text { that Democrat is a High } \\
\text { Quality Candidate (upper } \\
\text { and lower bounds) }\end{array}$ \\
\hline $\begin{array}{c}\text { Year of Election (for districts } \\
\text { with a } 22.8 \% \text { recall surge) }\end{array}$ & 2002 to 2004 & $\begin{array}{l}15 \% \text { increase } \\
(-5 \%, 34 \%)\end{array}$ & $\begin{array}{l}26 \% \text { decrease } \\
(-44 \%,-4 \%)\end{array}$ \\
\hline $\begin{array}{c}\text { Year of Election (for districts } \\
\text { with a } 14.4 \% \text { recall surge) }\end{array}$ & 2002 to 2004 & $\begin{array}{c}16 \% \text { decrease } \\
(-35 \%, 5 \%)\end{array}$ & $\begin{array}{l}19 \% \text { increase } \\
(-15 \%, 49 \%)\end{array}$ \\
\hline Democratic Registration & $42.5 \%$ to $71.7 \%$ & $\begin{array}{l}21 \% \text { decrease } \\
(-51 \%, 8 \%)\end{array}$ & $\begin{array}{c}43 \% \text { increase } \\
(8 \%, 73 \%)\end{array}$ \\
\hline $\begin{array}{l}\text { Conservative Incumbent } \\
\text { from the Other Party }\end{array}$ & Absent to Present & $\begin{array}{l}21 \% \text { decrease } \\
(-40 \%, 3 \%)\end{array}$ & $\begin{array}{l}28 \% \text { decrease } \\
(-46 \%,-8 \%)\end{array}$ \\
\hline $\begin{array}{l}\text { Liberal Incumbent from the } \\
\text { Other Party }\end{array}$ & Absent to Present & $\begin{array}{l}17 \% \text { decrease } \\
(-36 \%, 4 \%)\end{array}$ & $\begin{array}{l}11 \% \text { decrease } \\
(-16 \%, 40 \%)\end{array}$ \\
\hline Average Household Income & $\$ 45,804$ to $\$ 80,690$ & $\begin{array}{c}20 \% \text { decrease } \\
(-43 \%, 2 \%)\end{array}$ & $\begin{array}{l}27 \% \text { increase } \\
(2 \%, 55 \%)\end{array}$ \\
\hline Black Population & $0 \%$ to $13.7 \%$ & $\begin{array}{l}12 \% \text { decrease } \\
(-38 \%, 13 \%)\end{array}$ & $\begin{array}{l}4 \% \text { increase } \\
(-27 \%, 34 \%)\end{array}$ \\
\hline Latino Population & $13.1 \%$ to $51.7 \%$ & $\begin{array}{l}26 \% \text { decrease } \\
(-49 \%,-.4 \%)\end{array}$ & $\begin{array}{l}2 \% \text { increase } \\
(-27 \%, 30 \%)\end{array}$ \\
\hline $\begin{array}{l}\text { Asian-Pacific Islander } \\
\text { Population }\end{array}$ & $2.5 \%$ to $19.9 \%$ & $\begin{array}{l}1 \% \text { increase } \\
(-17 \%, 18 \%)\end{array}$ & $\begin{array}{l}3 \% \text { decrease } \\
(-31 \%, 27 \%)\end{array}$ \\
\hline
\end{tabular}

Notes: Boldface indicates that the first difference was generated by a coefficient or by coefficients that were statistically significant at the $95 \%$ confidence level in a one-tailed test. Upper and lower bounds show the $95 \%$ confidence level around a predicted first difference, which in the case "Year of Election" rows is generated by two countervailing coefficients. Based on an ordered probit model estimated in Stata 8.0, with first differences drawn from 1,000 simulations performed by CLARIFY (King, Tomz, and Wittenberg, 2000). 119 observations for Republican nominees, 95 observations for Democratic nominees. Pseudo R-squared equals .18 for the Republican model, .22 for the Democratic model.

of the raw coefficient estimates from which these first differences were derived is provided to the online appendix to this paper at www.journalofpolitics.org/ articles.html.) The first column presents results for the 119 Republicans nominated in races without a Republican incumbent, while the second column reports findings for Democratic quality in the 95 races without a Democratic incumbent. ${ }^{14}$

For both Republicans and Democrats, the chances of nominating an experienced candidate are contingent upon the size of the Republican surge. This fits with the strategic logic of our hypothesis, albeit in a

Democrats, the model predicted probabilities of $38 \%$ for nominating a high-quality candidate, $26 \%$ for a mid-quality, and $36 \%$ for a low-quality nominee.

${ }^{14}$ We exclude races with an incumbent from our sample because they provide no information to test our theory. Observing that races which already feature an incumbent, who is by definition a high-quality candidate, result in the nomination of a high-quality candidate reveals nothing about strategic entry decisions. We might learn about strategic exit if Democratic incumbents retired when facing a strong recall surge, but-perhaps due to the presence of term limits — we have identified no cases of strategic retirement. more subtle way than we initially expected. First, consider Republican candidates. In districts where the recall surge measured 22.8 percentage points, one standard deviation higher than average, experienced local officeholders saw an opportunity to win an Assembly seat and the Republican Party became 15\% more likely to nominate a high-quality candidate. Yet in districts where the recall surge was relatively weak, potential Republican candidates appeared to be more pessimistic. Where it measured only 14.4 points, well below average, the Republican nominee was $16 \%$ less likely to have major elective experience in 2004 than in 2002. Although the $95 \%$ confidence intervals around these first-difference estimates contain zero, both are constructed from the statistically significant coefficients of the year indicator and its interaction with the Republican surge, which have countervailing effects.

Just as experienced officeholders from the Republican side were tempted into Assembly primaries where the recall surge was strong, quality Democrats appear to have bowed out of races if the 2003 results boded badly for them. The second column of Table 1 shows that the Democrats were $26 \%$ less likely to get a 
high-quality nominee in 2004 in districts where the recall surge was strong. On the other hand, where Schwarzenegger and McClintock did worse than average, Democrats were more likely to nominate an experienced candidate in 2004 than in 2002.

Our major finding here is that the Republican surge in the 2003 recall sent a signal that the pool of high-quality Assembly candidates heeded. In districts where that surge was strong, Republicans were more likely to nominate candidates with prior experience while Democrats were less likely to have a high-quality nominee, all other political factors being equal. Let us return to the case of the 62nd Assembly District, the Democratic-leaning seat in San Bernardino County where Schwarzenegger and McClintock's combined vote in 2003 was $26.4 \%$ higher than Simon's in 2002. In that year, the model predicted only an $8 \%$ chance that the Republicans would have an experienced nominee, and they in fact nominated a business owner. In 2004, after the recall surge, the model predicted a 52\% probability that Republicans would nominate a high-quality candidate, and they were able to recruit a school board member.

\section{The Recall and Legislative Voting Behavior}

As high-quality Republican candidates emerged to challenge them, did Democratic incumbents moderate their voting patterns in response to the electoral threat signaled by the recall? Did Republican incumbents, less likely to face experienced Democratic opponents in 2004 than they were in 2002, shift away from the center as they became more confident that they would win reelection? The change in challenger quality provides one reason to believe that legislators should change their behavior after the recall. Perhaps a more powerful prediction comes from the way that the recall communicated a shift in constituent preferences that altered political incentives in Sacramento.

Many political observers expected Democratic legislators to shift to the right after the recall, with especially strong shifts coming in the competitive districts where the recall's Republican surge could translate into a real electoral threat. Key strategists clearly identified these seats. Republican consultant Dan Schnur predicted that "Every one of the Democratic legislators in districts that voted for Schwarzenegger 'is going to have to campaign as if they are vulnerable' " (Vogel 2004). Still, some of those advising Democratic Assembly members provided reasons why they should not be swayed. Democratic consultant Darry Sragow argued that "[Schwarzenegger's] popularity is fairly unique to him, his base is unique to him, and I think the sense on the Democratic side is that while he cannot be taken lightly, there's no fear that he's going to eat the minds of the voters" (Rau 2004). As Schwarzenegger toured the state warning vulnerable Democrats that they would pay an electoral price if they failed to vote with him on the budget, state Democratic Party Chair Art Torres said of Schwarzenegger: "He consistently threatens; he never produces" (Nicholas and Halper 2004).

In the online appendix, we present a simple model of incumbent positioning in elections that demonstrates formally the existence of conditions under which incumbents would be expected to be responsive to perceived changes in the location of their median voters and conditions under which ex ante safer incumbents would shift less than incumbents representing more electorally safe districts. Interestingly, while these two predictions are quite intuitive, the conditions under which they hold is less general than one might imagine, as we demonstrate in several counterexamples. Nevertheless, there are microtheoretical foundations supporting the prediction that Democratic incumbents would move to the right in response the recall election and that Democrats from more marginal districts would be expected to move more.

Our empirical analysis, presented below, reveals that the recall threat did produce significant Democratic moderation. Surprisingly, Republicans also moderated, although to a lesser extent. While moderation in the second year of the term (the one ending with Assembly elections) might be expected to occur even without the recall, we show that no such moderation took place in the year preceding the 2002 election. Indeed, we find somewhat more partisan polarization in 2002 than 2001 . We estimate that moderation by Democrats in the postrecall period increased the expected number of Democrats siding with the majority of Republicans on closely contested roll calls by one to two votes on average and by as many as six to eight votes in some cases.

The research design presented in this section is more straightforward than our comparison of the 2002 and 2004 primaries, with their shifting casts and political conditions. We examine the behavior of the same individuals, California's 80 Assembly members, before and after the recall took place. This is a basic "interrupted time series" design, and while we probe for treatment effects we will also have to consider some standard threats to validity (Campbell and Ross 1968) such as maturation and regression to the 
mean. ${ }^{15}$ In order to estimate the ideological locations of the California's 80 Assembly members, we applied Poole and Rosenthal's NOMINATE procedure for recovering legislators ideological positions from their roll-call votes. We compiled the results of all 1,901 roll-call votes taken during 2003 and 2004 in which at least two members voted on the losing side. Of these roll calls, $903(47.5 \%)$ were taken before the recall and 998 (52.5\%) were taken after the recall. Because the underlying ideological dimensions recovered by NOMINATE for two separate sets of roll-call votes are not comparable, we could not simply apply NOMINATE to the prerecall votes and separately apply NOMINATE to the postrecall votes and then measure the change in each Assembly member's location. In order to locate each Assembly member pre- and postrecall in the same space, we assumed that the electoral prospects of Assembly members representing the 27 safest districts ${ }^{16}$ would not be affected by the recall and thus these members would not change their voting behavior subsequent to the recall. ${ }^{17}$ We then estimate a

\footnotetext{
${ }^{15}$ Since the October 7, 2003 recall was held at the midpoint of the 2003-2004 Session, it divides the collection of floor votes into off-year and election-year votes. Suppose we observe Democratic legislators moving toward the political center. This could be a response to Schwarzenegger and McClintock's strong showings, or the result of a maturation process, a natural drift of both party's members to the center in the second half of a legislative session. Another possibility is that we see Republican legislators who had relatively moderate voting records before the recall moving back toward their party's mean position in the second half of the session. This could be evidence that they felt safer after the recall demonstrated Republican strength, or it could simply reflect a regression to the mean that is often seen in repeated tests. To guard against these threats to inference, we analyze roll-call behavior in three other sessions, divided up into first-year and election-year voting records.
}

${ }^{16}$ We defined "safe" seats, somewhat arbitrarily, as those in which Democratic voters made up at least $70 \%$ of major party registrants and those in which Republicans made up at least $60 \%$. We employed this asymmetric measure of competitiveness because Kousser's (1996) analysis of California Assembly districts and election results shows that fewer Republican voters are needed to produce a given percentage of the vote because they turn out a higher rates and exhibit greater party loyalty.

${ }^{17}$ If no members changed positions across the pre- and postrecall periods, then our identifying constraints are innocuous, so our procedure is consistent under the null. On the other hand, if all members changed positions (including the ones that we constrain), then the changes in positions that we estimate will be (more or less) changes relative to the changes in the positions of the members whose locations we fixed. If, for example, the Democratic party members whom we constrained actually moved in the same direction as the unconstrained Democrats, we would underestimate the true Democratic response, because our estimates would only be capturing the differences between the moves made by the unconstrained members relative to the constrained members. On the other hand, it is also possible that the positions of the Democrats that we left unconstrained remained fixed and single NOMINATE model in which separate a ideal points are estimated for the 53 unconstrained members and a single ideal point is estimated for the 27 constrained members. Because the constrained members pin down the location scale and rotation of the issue space across the two periods, the ideal points and other NOMINATE parameters are comparable across the two periods, and we can meaningfully consider changes in the ideal points of the unconstrained members across periods.

The fit of the NOMINATE model to the Assembly roll-call voting is exceptionally strong. A single dimension correctly classifies $95.5 \%$ of the votes and reduces classification error over a naïve model in which all members vote with the majority by $84.1 \%$. Adding an additional dimension increases model fit by only .2 percentage points. We find in the California Assembly unidimensional voting behavior that exceeds that found in the contemporary U.S. Congress, which is touted as being as unidimensional as it has ever been (Poole and Rosenthal 1997). For example, Poole finds that a single dimension correctly classifies $92.1 \%$ of U.S. Senate votes and reduces prediction error by $79.6 \%$, while a second dimension increases classification by one percentage point (Poole, personal correspondence). Due to this very strong unidimensionality, in what follows we consider only changes in members' first-dimension NOMINATE scores.

Figure 1 presents our NOMINATE estimates of Assembly members' locations. The solid dots are point estimates of the left-right position of each Assembly member before the recall. The open dots represent the left-right positions of Assembly members after the recall. Members having only solid dots were constrained to have a single position across the two periods. The line going through each point is a $95 \%$ confidence interval estimated using the parametric bootstrap procedure described in Lewis and Poole (2004). The members are arranged from most conser-

the Democrats that we assumed fixed actually moved in the opposite direction to our estimates (became more extreme). This is a fundamental identification problem in the estimation of spatial locations from observed vote choices. The identifying assumption must be maintained, and while consistent with theory, is largely untestable. However, our faith in our results is bolstered by their robustness when we use another criterion to constrain members. In addition to constraining the 27 safest members, we reran the analysis fixing those members who due to California's term limit law could not run again for the Assembly. The results are substantially similar to those reported in the text. However, because termed out Assembly members often contest other electoral offices in similar districts (Osborne 2004; Yang 2002) subsequent to being termed out of the Assembly, we decided that constraining safe district members was the more justifiable constraint. 


\section{Figure 1 2003-2004 California Assembly Members' First Dimension NOMINATE Scores Before and After the Gubernatorial Recall}

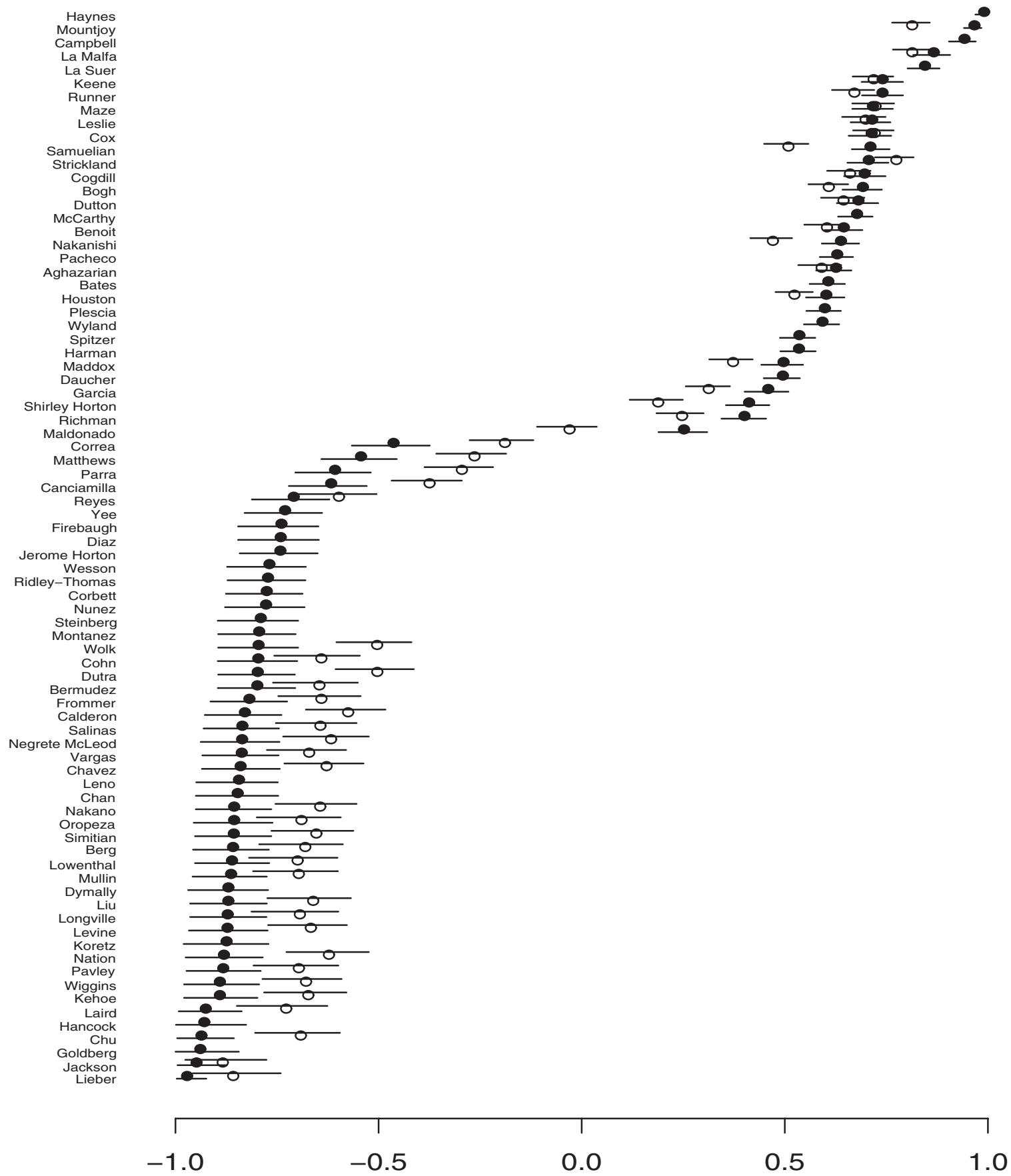

NOMINATE score

The figure shows point estimates and confidence intervals for the first dimension NOMINATE scores of each of the 80 members of the California Assembly during the 2003-2004 session. The solid dots represent prerecall positions. The open dots represent postrecall positions. The locations of members from the 27 safest districts are fixed across the two periods in order to identify the changes in the locations of the others (as described in the text). The fixed members are represented by a single solid dot.

vative (prior to the recall) at the top of the figure to most liberal at the bottom.

As hypothesized, Democratic members moderated in response to the recall. Indeed, every uncon- strained Democrat is estimated to be more conservative in the postrecall period than in the prerecall position. For many of these members, the confidence intervals of the estimates for each period do 
not overlap, revealing the high degree of statistical significance of those shifts. (Note that statistical significance at the $95 \%$ confidence level does not require that the confidence intervals be nonoverlapping.) For all but one of the 32 unconstrained Democrats, the rightward shift is significant at the $95 \%$ confidence level in a two-tailed test. The estimated average shift in the Democrats positions was .20 with a $95 \%$ confidence interval of .18 to .22, or approximately $10 \%$ of the distance between the most liberal and most conservative member (defined by NOMINATE as -1 and 1 , respectively).

Contrary to our expectations, Assembly Republicans did not move rightward following the recall. Indeed many of the Republicans moderated significantly. Of the 21 unconstrained Republicans, 11 shifted significantly to the left. None moved significantly to the right. Overall, we reject a null of no movement for $97 \%$ of Democrats and 62\% of Republicans, despite the smaller standard errors associated with the estimated positions of Republicans. For Republicans on average, the leftward move was estimated to be -.08 with a $95 \%$ confidence interval of -.10 to -.075 . Thus the Republican moderation was only about half as large on average as the postrecall moderation shown by Democrats. Still, even though the shifts toward the center by Republicans were less frequent and less profound than shifts by Democrats, they still represent a puzzle for our initial hypothesis that the recall would embolden Republican incumbents to move rightward.

Perhaps the solution to this puzzle lies in the richness of the political information conveyed by the recall results. The dismal showing of Cruz Bustamante, the sole Democratic standard-bearer in the recall, sent a simple signal that the median voter in many Democratic-held districts was not as far to the left as Bustamante. But because the race featured two major Republican candidates, the relative performances of the moderate Arnold Schwarzenegger and the conservative Tom McClintock provided even more detail about the location of the median voter in districts that voted Republican in the recall: this voter appeared to be a centrist. Schwarzenegger was quite notably pro-choice, openly friendly with many prominent members of California's gay community, and supportive of gun control and environmental regulations. Running from the center, he captured at least $70 \%$ of the combined Schwarzenegger/McClintock vote total in every Republican-held district. This mandate for moderation may have been news to some Republicans, who only had the vote share of conservative Republican Bill Simon in the 2002 gubernatorial election to guide them. Viewed in this way, members of both parties received new information indicating that their district's median voter was closer to the center than they previously supposed, and reacted accordingly. We found some (admittedly tepid) support for this notion by testing the post-hoc hypothesis that Republicans were more likely to shift to the center in districts where Schwarzenegger did relatively well compared to McClintock..$^{18}$

Returning to our overall analysis, in order to determine the statistical significance of the average shifts in Democratic and Republican positions, we constructed 500 data sets in which the 1,901 contested Assembly roll calls were randomly divided into pseudo pre- and postsubsets. Each pseudo pre- and postperiod contained the same number of votes as were taken in the actual pre- and postrecall period. Constraining the positions of the same 27 safe members, we estimated the change in the unconstrained members' locations across the pseudo pre- and postrecall periods in each of the 500 constructed data sets. Under the null hypothesis that there was no change in Assembly member's ideal points following the recall, the estimated changes in ideal points that we found across the two periods should be similar in magnitude to the changes found in our 500 random partitions. By contrast, if the observed change proves atypical of the randomly drawn partitions, we will reject the null hypothesis that the legislators maintained consistent positions after the recall.

The distribution of the estimated changes across the 500 constructed data sets is presented in Figure 2. The solid dot in each panel represents the change in the average position for the given party between the actual pre- and postrecall periods. For both Democrats and Republicans, the observed shift between the pre- and postrecall periods was considerably larger than the shift found in any of the 500 random partitions allowing us to reject, at a $99.8 \%$ confidence level,

\footnotetext{
${ }^{18}$ To conduct this test, we divided the 21 unconstrained Republicans into two groups based on Schwarzenegger's percentage of the total vote cast for both Schwarzenegger and McClintock in October, 2003. We expected that Assembly members from the 10 districts in which Schwarzenegger did particularly well relative to his more conservative copartisan would be most likely to moderate their positions after the recall. Indeed, six of these 10 legislators made statistically significant moves toward the center, and their centrist shift averaged .105 with a standard deviation of .113. But some of the Republicans from the 11 districts in which McClintock did particularly well also moved toward the center. Five of these 11 legislators made a statistically significant centrist move, and their shift averaged .72 with a standard deviation of .056 . The difference between these mean shifts is not significant at the $95 \%$ confidence level.
} 


\section{Figure 2 Distribution of the Average Change in Assembly Members' First-dimension NOMINATE Scores by Party Across 500 Random Divisions of the Roll Calls Cast During 2003-2004}

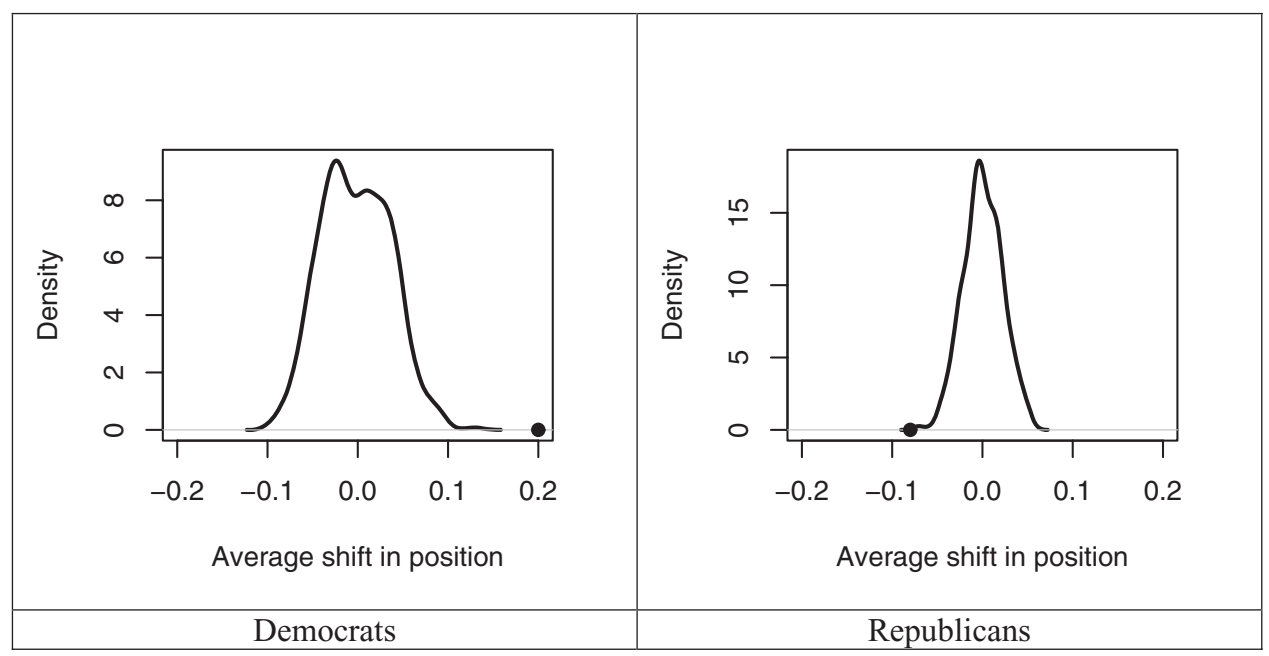

Each panel is a kernel density plot of the distribution of the average change in the first dimension NOMINATE location of the given party's members across randomly generated divisions of the roll calls cast during 2003-2004. In each of the 500 divisions, 903 votes (equal to the number of contested roll calls cast before the recall) were allocated to the first subset and 998 votes (equal to the number of contested roll calls cast after the recall) were allocated to the second subset. The solid dot on each plot shows the average change in the location found when the roll calls are divided into pre- and postrecall periods. For the Democrats, the pre-/postrecall split generated a larger shift than was found in any of the 500 random divisions.

the null hypothesis that the observed change could result from random variation.

If the shift in voting patterns between 2003 and 2004 is real, can we be sure that it was caused by the recall? Particularly because both the Republican and the Democratic caucus moderated in the postrecall period, a reasonable alternative hypothesis ${ }^{19}$ is that this moderation is not due to the extraordinary politics of the recall, but rather is the result of a normal political pressure to moderate in the period immediately preceding an election (see Cain and Kousser 2004; Figlio 2000). In order to investigate the possibility that moderation of position in the second year of an Assembly session is the norm, we collected California Assembly roll-call voting data from 2001 to 2002. As we did for the 2003-2004 term, we split the votes into pre- and post-October 7 th periods and constrained the electorally safest members' positions to be fixed across the

\footnotetext{
${ }^{19}$ Another alternative explanation-that the shift in legislative behavior was caused by a shift in the legislative agenda when Gov. Schwarzenegger came to office-seems less plausible. In California, governors do not have the ability to shape the legislative agenda formally by introducing or sponsoring bills. They may attempt to informally influence the agenda, but legislative leaders have the ability to resist these moves. The major issues that the California Legislature dealt with in the year following the recall, such as a budget deficit, workers' compensation, driver's licenses for undocumented residents, and consumer privacy, were the same issues that it considered in the year leading up to the recall.
}

two periods. The estimated NOMINATE positions of members of the 2001-2002 Assembly are shown in Figure $3 .^{20}$ Overall, the shifts observed in the second half of the 2001-2002 session are considerably smaller than those found in 2003-2004. And, far from moderating, members of both parties actually became more partisan in the second year of the 2001-2002 session.

While the comparison of 2003-2004 to 2001-2002 does not definitively rule out the possibility that the shifts in position observed in the 2003-2004 session were due to something other than the recall, the comparison does cast considerable doubt on the leading alternative hypothesis of second-year moderation. Further evidence against the hypothesis of secondyear moderation is presented in Table 2. Considering all roll calls cast between 1997 and 2004, we find that not only is the average shift in the positions of Assembly Democrats significantly larger in 2003-2004 than it is for either caucus in 2001-2002, but it is also significantly larger than for either caucus in 1997-98 or 1999-2000. Moreover, 2003-2004 is the only legislative session in which the Democrats, the majority party throughout this time period, moderated.

\footnotetext{
${ }^{20}$ A single NOMINATE dimension correctly classifies $95.0 \%$ of the 2001-2002 vote choices with proportionate reduction in error of $80.2 \%$. Adding another dimension only increases the fit by .4 percentage points.
} 


\section{FIgURE 3 2001-2002 California Assembly Members' First Dimension NOMINATE Scores Before and After October 7, 2001}

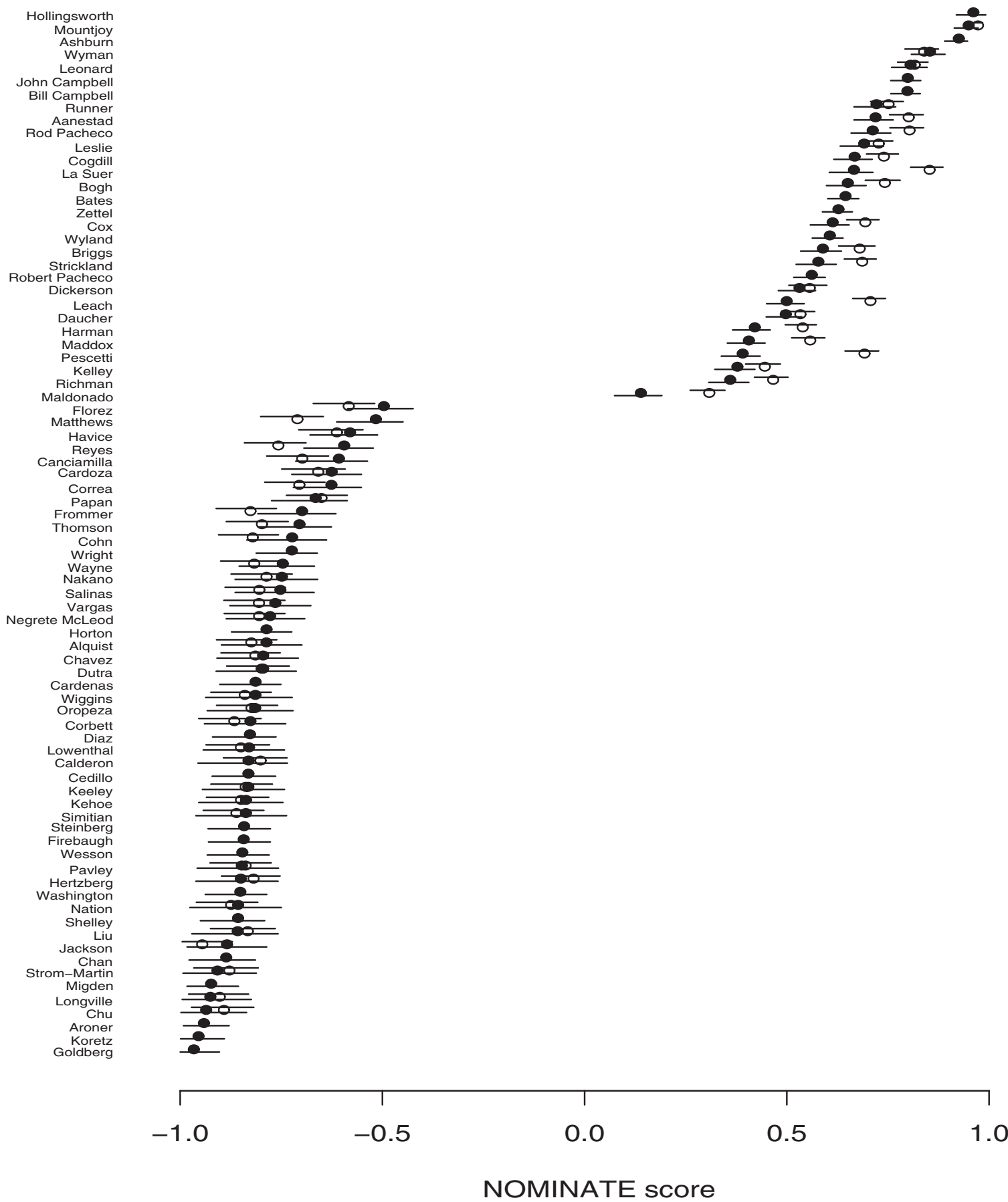

The figure shows point estimates and confidence intervals for the first dimension NOMINATE scores of each of the 80 members of the California Assembly during the 2001-2002 session. The solid dots represent pre-October 7, 2001 positions. The open dots represent post-October 7, 2001 positions. The locations of members from the 23 safest districts are fixed across the two periods in order to identify the changes in the locations of the others (as described in the text). The fixed members are represented by a single solid dot.

What are the substantive magnitudes of these statistically significant shifts? As noted above, the average shift in Democratic members' positions was about $10 \%$ of the ideological range. In terms of the variation within the Democratic caucus, the change appears even more important. The average shift in the positions of Democratic members from the pre- to the postrecall period was 1.7 times as large as the standard 
TABle 2 Average Shift in First Dimension NOMINATE Scores by Party, 1997-2004

\begin{tabular}{lcc}
\hline & Democrats & Republicans \\
\hline $1997-98$ & -.04 & -.14 \\
& $(-.05,-.03)$ & $(-.15,-.11)$ \\
$1999-00$ & -.11 & -.03 \\
& $(-.13,-.09)$ & $(-.05,-.02)$ \\
$2001-02$ & -.03 & .09 \\
& $(-.06,-.02)$ & $(.08, .11)$ \\
$2003-2004$ & .20 & -.08 \\
& $(.18, .22)$ & $(-.10,-.07)$ \\
\hline
\end{tabular}

Table shows the average difference between the NOMINATE scores of California Assembly members based on votes taken before October 7th and votes taken after October 7th of the oddnumbered year of each two-year legislative session. Note that shifts observed for Democrats during the 2003-2004 session (the period covering the 2003 recall) are twice as large than those of any other period and that 2003-2004 is the only period in which Democrats became more conservative over the course of the session. Ninetyfive percent confidence intervals for each estimated shift are shown in parentheses.

deviation of the prerecall Democratic positions. Consider the case of John Laird, a Santa Cruz Assembly member who was the third most liberal Democrat in the year before the recall. After the 2003 contest, his ideology shifted so far rightward that it was more conservative than the prerecall positions of all Democrats but the party's four most moderate members. And these moderates in competitive districts-Lou Correa, Barbara Matthews, Nicole Parra, and Joseph Canciamilla-moved especially far to the right after the recall.

A more concrete way to measure the degree to which changes in position were substantively important is to pose the following hypothetical question: if the Assembly members had all maintained their prerecall positions and the postrecall agenda had remained unchanged, how many fewer Democrats would have voted with the majority of Republicans on each bill? In other words, how many extra votes was Schwarzenegger able to command, not because he was able to affect the voting agenda, but because Democrats in the postrecall period took more moderate positions? Because the NOMINATE model provides estimates not only of the positions of the legislators, but also of the yea and nay locations for each vote, we have the ingredients necessary to address this counterfactual. Evaluating NOMINATE's underlying probabilistic choice model at the yea and nay locations of each of the postrecall roll calls and at the ideal points from both the pre- and postrecall periods, we obtained estimates of the probability that each Democrat would vote on the same side as a majority of the Republicans on each bill, when located first at their pre- and then at their postrecall positions. ${ }^{21}$ Given these probabilities, we are able to estimate the average increase in the number of Democrats voting with the majority of Republicans that was due solely to Democratic moderation after the recall. Focusing on 246 postrecall roll calls with majority sizes of less than $60 \%$ (nonlopsided votes), we estimate that on average 1.3 more Democrats voted with the majority of Republicans after the recall due to policy moderation. The $95 \%$ confidence interval derived via the parametric bootstrap for this estimate ranges from 1.1 to 1.5. Given that the Assembly has only 80 members and that the nonlopsided roll calls have only 40 to 48 members voting in the majority, this shift is substantial.

Moreover, we find considerable variation across roll calls. Figure 4 presents a histogram of the point estimates of the moderation-induced shifts in the number of Democrats voting with the majority of Republicans across the 246 nonlopsided votes. For 38 of the votes, three or more additional Democrats are estimated to have voted with the majority of Republicans due to their post-recall policy moderation. A predicted four or more Democrats switched sides on roll calls such as bills to adjust health facilities staffing ( $\mathrm{AB}$ 1927), a vote on air pollution regulation (AB 2705), and votes on local government finance and property taxes (SB 407 and SB 17). Thus, while Democratic moderation had a minimal effect on about one-half of the nonlopsided roll calls, its effect on many of the remaining votes was considerable.

\section{Conclusions}

The substantively and statistically significant shifts in voting patterns that we observe in California suggest larger lessons for the study of legislators' ideological positions. They demonstrate that strategic legislators can adapt their voting behavior to fit the preferences of their constituents. This should not be surprising, given theories of democratic responsiveness motivated by the electoral connection (Downs 1957; Mayhew 1974),

\footnotetext{
${ }^{21}$ In addition to the location of the legislators' ideal points and the yea and no positions, calculations of NOMINATE choice probabilities also require values for the beta and weight parameters (Poole and Rosenthal 1997). Estimates of these parameters from NOMINATE were used in the calculation of the choice probabilities. In order to minimize the effects of abstention on particular votes, we calculated the average change vote probabilities by supposing that all Democrats voted on all bills for the purposes of the counterfactual.
} 


\section{FIgURE 4 Distribution of the Estimated Increase in the Number of Democrats Voting with a Majority of Republicans across Nonlopsided Postrecall Roll Calls Due to Democratic Moderation}

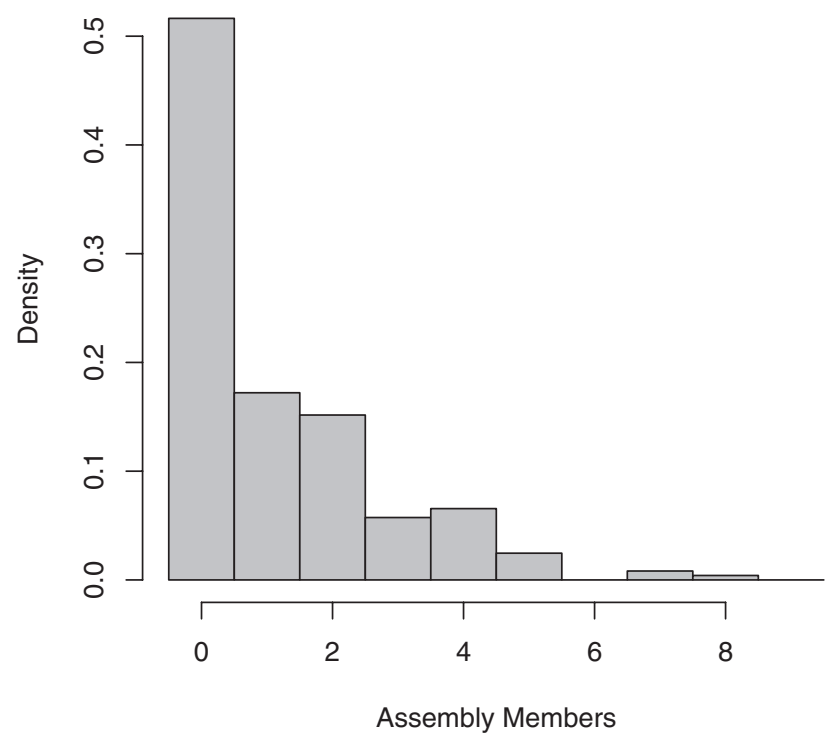

Histogram of the estimated increase in the number of Democrats voting with the majority of Assembly Republicans across the 246 postrecall roll calls having majority sizes of less than $60 \%$ due solely to moderation in Democrats' positions following the recall. While roughly one-half of these roll calls reveal no preference-shift-induced increase in the number of Democrats voting with the majority of Republicans, in some $10 \%$ of cases, we estimate that four or more extra Democratic votes were moved to the Republican side due to the rightward shifts in Democrats' positions following the recall.

but it runs counter to an empirical literature that has found little evidence of ideological mobility (Grofman, Griffin, and Berry 1995; Levitt 1996; Lott 1987; Lott and Bronars 1993; Poole 1998; Poole and Romer 1993; Van Beek 1991). Our findings present evidence on the side of works like Hibbing (1986), Figlio (1995), Jenkins (2000), Tien (2001), Wright and Schaffner (2002), Snyder and Ting (2003), and Grossback et al. (2005) that legislators alter their voting positions when their incentives and constraints change. It also serves as an important reminder that ideal point estimates-sometimes treated as representations of the pure preferences of legislators - are of course revealed preferences constructed from behavioral patterns that may be influenced by factors as varied as personal policy positions, party pressures, and adjustments to electoral signals.

Another implication of this research is that Downsian pressures can operate even on legislators who represent districts that are not controlled by razor-thin margins. Recent contentions in the popular press (e.g.,
Eilperin 2006; Los Angeles Times 2005) hold that American politics now features largely uncompetitive districts in which incumbents have no reason to be responsive to voters. Even though California's most recent redistricting reduced the number of seats in which the parties were evenly matched, our results show that many districts were still sufficiently competitive that legislators felt electoral pressures and responded to voter demands. In 2004, eight Democrats ran for reelection in districts where their party's registration edge ranged from 10 to $20 \%$ of major party registrants. All eight moved toward the center after the recall. Even in seats that most political observers might categorize as safe, incumbents appear to feel "unsafe at any margin" (Mann 1978) and to be "running scared" (Jacobson 1987).

Third, from a methodological perspective, it is our hope that this study is a convincing demonstration of the sort of insight that can arise from looking beyond the U.S. Congress to find new and largely untapped testing grounds for general theories of legislative behavior. Our results turn on a natural experiment presented by a particular feature of California's political institutions that does not exist at the national level. We believe that other institutional features of state legislatures make them fertile ground for similar experimentation. For example, Colorado's 1988 GAVEL initiative greatly weakened committee chairs and party caucuses in that state's legislature and was exogenous to the preferences of legislators themselves. Similarly, federal policy mandates can similarly reshape the state-level political landscape in ways that are largely independent of the preference of state-level actors. As roll-call voting, electoral, campaign finance, and other data related to state legislatures have become more cheaply and readily available (for example, Gerald Wright's archive of state roll-call records and the gubernatorial approval ratings database of Niemi, Beyle, and Sigelman), many similar opportunities for natural experimentation in the context of state politics are now present.

Fourth, our findings suggest a new interpretation of the impact that the 2003 recall election had on Californian politics. In the immediate wake of the recall, many political strategists speculated that Arnold Schwarzenegger's victory and subsequent popularity would aid Republican legislative candidates. Yet the 2004 election results seemed to show that Schwarzenegger had no coattails. There were 23 Assembly seats held by Democrats in which a majority voted for a Republican governor in 2003, but Republicans failed to capture any of these seats in 2004 (California Secretary of the State 2003a, 2003b, 2004a, 
2004b). Indeed, none of the open seats in which Schwarzenegger endorsed candidates went Republican, and the three Democratic legislators he targeted for termination (Sen. Michael Machado and Assembly members Barbara Matthews and Nicole Parra) retained their seats. One interpretation of these findings is simply that the recall was an isolated event in California politics and that Schwarzenegger's personal popularity has not changed legislative politics or rubbed off on his party.

Our findings point to a different story with the same ending. It appears that the recall did influence the entry decisions of candidates, causing tougher challengers to face incumbent Democrats. These incumbents looked at the results of the recall in their districts, saw the qualifications of their opponents, and perhaps even witnessed a Schwarzenegger visit to their backyard. In response, they moderated their voting patterns to help their electoral chances. The fact that all of the Democrats made vulnerable by the recall survived in 2004 may be a testament to their rational responses to the signal that it sent, rather than evidence of its irrelevance.

Manuscript submitted 18 November 2005

Manuscript accepted for publication 18 December 2006

\section{References}

Ainsworth, Bill. 2004. “Governor's Tough Talk Criticized as Partisan." San Diego Union Tribune, 21 July.

Bluth, Alexa H. 2004. "Governor Plans Sixth Budget Trip.” Sacramento Bee, 21 July.

Cain, Bruce E., and Thad Kousser. 2004. Adapting to Term Limits: Recent Experiences and New Directions. San Francisco: Public Policy Institute of California.

California Journal and Statenet. 2004. Roster and Government Guide, 2004. Sacramento: California Journal and Statenet.

California Secretary of the State. 2002a. "February 19, 2002 Report of Registration.” http://www.ss.ca.gov/elections/ ror_021902.htm (April 2004).

California Secretary of the State. 2002b. "Statement of Vote, 2002 Primary Election.” http://www.ss.ca.gov/elections/sov/ 2002_primary/contents.htm (April 2004).

California Secretary of the State. 2002c. "Statement of Vote, 2004 General Election." http://www.ss.ca.gov/elections/sov/ 2004_general/contents.htm (December 2004).

California Secretary of the State. 2002d. "Supplement to the Statement of Vote, 2002 General Election.” http://www.ss.ca.gov/ elections/sov/2002_general/contents.htm (April 2004).

California Secretary of the State. 2003a. "September 22, 2003 Report of Registration.” http://www.ss.ca.gov/elections/ ror_092203.htm (April 2004).

California Secretary of the State. 2003b. "Supplement to the Statement of Vote, 2003 Statewide Special Election.” http:// www.ss.ca.gov/elections/sov/2003_special/contents.htm (April 2004).
California Secretary of the State. 2004a. "February 17, 2004 Report of Registration.” http://www.ss.ca.gov/elections/ror_02172004. htm (April 2004).

California Secretary of the State. 2004b. "Statement of Vote, 2004 Primary Election.” http://www.ss.ca.gov/elections/sov/ 2004_primary/contents.htm (April 2004).

California Secretary of the State. 2004c. "Summary of Qualification and Requirements for Partisan Nomination for the Offices of State Senator and Member of the State Assembly." http:// www.ss.ca.gov/elections/cand_qual_leg.pdf (October 2005).

California Statewide Database. 2004. "2000 Census Data: Assembly, Senate, and Congressional District Reports." http:// swdb.berkeley.edu/info/census2000/census.html (April 2004).

Campbell, Donald, and H. Laurence Ross. 1968. "The Connecticut Crackdown on Speeding: Time Series Data in QuasiExperimental Analysis." Law and Society Review 3 (1): 33-53.

Crook, Sara Brandes, and John R. Hibbing. 1985. “Congressional Reform and Party Discipline: The Effects of Changes in the Seniority System on Party Loyalty in the US House of Representatives." British Journal of Political Science 15 (2): 207-26.

Den Hartog, Chris, and Nathan Monroe. 2006. "The Value of Majority Status: The Effect of Jeffords's Switch on Asset Prices of Republican and Democratic Firms." Typescript. Michigan State University.

DiCamillo, Mark, and Mervin Field, 2004. "Californians Continue to Give Governor Very High Job Approval Marks" The Field Poll, Release \#2125.

Downs, Anthony. 1957. An Economic Theory of Democracy. New York: Harper and Row.

Eilperin, Juliet. 2006. Fight Club Politics: How Partisanship is Poisoning the House of Representatives. Lanham, MD: Rowman \& Littlefield.

Figlio, David N. 1995. "The Effect of Retirement on Political Shirking: Evidence from Congressional Voting." Public Finance Quarterly 23 (2): 226-41.

Figlio, David N. 2000. "Political Shirking, Opponent Quality, and Electoral Support." Public Choice 103 (3-4): 171-244.

Grofman, Bernard, Robert Griffin, and Gregory Berry. 1995. "House Members Who Become Senators: Learning from a 'Natural Experiment' in Representation.” Legislative Studies Quarterly 20 (4): 513-29.

Groseclose, Timothy. 2001. "A Model of Candidate Location When One Candidate Has a Valence Advantage." American Journal of Political Science. 45: 862-886.

Grossback, Lawrence J., David A. M. Peterson, and James A. Stimson. 2005. "Comparing Competing Theories on the Causes of Mandate Perceptions." American Journal of Political Science 49 (2): 406-19.

Hibbing, John R. 1986. "Ambition in the House: Behavioral Consequences of Higher Office Goals Among U.S. Representatives." American Journal of Political Science 30 (3): 651-65.

Hoffenblum, Alan, ed. 2004. California Target Book, Volume 4, 2004 General Election Edition. Los Angeles: Alan Hoffenblum and Associates.

Jacobson, Gary C. 1987. "Running Scared: Elections and Congressional Politics in the 1980s." In Congress: Structure and Policy, ed. Mathew D. McCubbins and Terry Sullivan. New York: Cambridge University Press.

Jacobson, Gary C., and Samuel Kernell. 1983. Strategy and Choice in Congressional Elections, Second edition. New Haven, CT: Yale University Press.

Jenkins, Jeffery A. 2000. "Examining the Robustness of Ideological Voting: Evidence from the Confederate House of Representatives." American Journal of Political Science 44 (4): 811-22. 
King, Gary, Michael Tomz, and Jason Wittenberg. 2000. "Making the Most of Statistical Analyses: Improving Interpretation and Presentation." American Journal of Political Science 44: 341-55.

Kousser, J. Morgan. 1996. "Estimating the Partisan Consequences of Redistricting Plans-Simply.” Legislative Studies Quarterly 21 (4): 521-41.

Kousser, Thad. 2004. “The California Governor's Recall.” In Keon Chi, editor, The Book of the States, 2004 Edition, Vol. 36. Lexington, KY: The Council of State Governments.

Legislative Counsel. 2005. "Bill Information." http:// www.leginfo.ca.gov/ (October 2005).

Levitt, Steven D. 1996. "How Do Senators Vote? Disentangling the Role of Voter Preferences, Party Affiliation, and Senator Ideology.” The American Economic Review 86 (3): 425-41.

Lewis, Jeffrey B., and Keith T. Poole. 2004. "Measuring Bias and Uncertainty in Ideal Point Estimates via the Parametric Bootstrap." Political Analysis 12 (2): 105-27.

Los Angeles Times Poll. 2003. “Los Angeles Times Poll \#2003-490: California Recall Election Exit Poll." Los Angeles Times.

Los Angeles Times. 2005. "Times Endorsement: A New Political Landscape." Los Angeles Times, 23 October, sec. M.

Lott, John R. 1987. "Political Cheating.” Public Choice 52 (2): 169_ 87.

Lott, John R., and Stephen G. Bronars. 1993. "Time Series Evidence on Shirking in the U.S. House of Representatives." Public Choice 76 (1-2): 125-49.

Mann, Thomas E. 1978. Unsafe at Any Margin: Interpreting Congressional Elections. Washington: American Enterprise Institute Press.

Mayhew, David R. 1974. Congress: The Electoral Connection. New Haven, CT: Yale University Press.

Nicholas, Peter, and Even Halper. 2004. "Governor Goes on the Road with His Threat to Unseat Democrats.” Los Angeles Times, 17 July, sec. B.
Osborne, Nathan. 2004. "California's Termed-Out LegislatorsWhere Do They Go?" Typescript. University of California, San Diego.

Poole, Keith T. 1998. “Changing Minds? Not in Congress!” Political Science Working Paper No. 1997: 22.

Poole, Keith T., and Howard Rosenthal. 1997. Congress: A PoliticalEconomic History of Roll Call Voting. New York: Oxford University Press.

Poole, Keith T., and Thomas Romer. 1993. "Ideology, 'Shirking,' and Representation." Public Choice 77 (1): 185-96.

Rau, Jordan. 2004. "Governor Has Tough Task in Ousting Foes." Los Angeles Times, 26 July, sec. B.

Snyder, James M., Jr., and Michael M. Ting. 2003. "Roll Calls, Party Labels, and Elections.” Political Analysis 11 (4): 419-44.

Tien, Charles. 2001. "Representation, Voluntary Retirement, and Shirking in the Last Term." Public Choice 106 (1-2): 117-30.

Van Beek, James R. 1991. "Does the Decision to Retire Increase the Amount of Political Shirking?” Public Finance Quarterly 19 (4): 444-56.

Vogel, Nancy. 2004. "Governor is a Wild Card in District Votes." Los Angeles Times, 15 February, sec. B.

Wright, Gerald C., and Brian F. Schaffner. 2002. "The Influence of Party: Evidence from the State Legislatures." American Political Science Review 96 (2): 367-79.

Yang, Kelly. 2002. Percentage of Termed-Out Members Who Run for Other Office. Berkeley, CA: Institute of Governmental Studies Research.

Thad Kousser is assistant professor of political science, University of California-San Diego, San Diego, CA 92093-0521. Jeffrey B. Lewis is assistant professor of political science, University of California-Los Angeles, Los Angeles, CA 900951472. Seth E. Masket is assistant professor of political science, University of Denver, Denver, CO 80208. 